\title{
E-GOVERNMENT VERSUS SMART GOVERNMENT: JORDAN VERSUS THE UNITED STATES
}

\author{
Andrii Glybovets \\ Department of Network Systems \\ National university "Kyiv-Mohyla academy" \\ 2 Scovorody str., Kyiv, Ukraine, 04070 \\ andriy@glybovets.com.ua \\ Mohammad Alhawawsha \\ Department of Information Systems \\ Taras Shevchnko National University of Kyiv \\ 60 Volodymyrska str., Kyiv, Ukraine, 01033 \\ mhawawsha@gmail.com
}

\begin{abstract}
The purpose of the research paper is to examine the differences between e-government and smart government and how will smart governments benefit modern public administrations and service delivery. It seeks to compare and contrast between smart government and e-government. In addition, it compares the application of smart government and e-government in the United States and Jordan. The research idea is based on the observation that the concept of e-government is relatively new in the modern world. Nevertheless, it has, in the last few decades, enabled governments to serve citizens using the internet technology. In addition, technology has allowed governments to obtain, process, manipulate, store, retrieve and report data on an efficient and reliable manner. The term 'e-government' refers to the development, adoption and use of information and communication technologies (ICTs) to improve the service delivery and activities of the public sector. Although there are many definitions of the term, it is generally agreed that the use of internet-enabled application to allow interactions between the government and outside groups are the key aspects of e-Government. An in-depth research method is based on the qualitative search of information from 13 credible sources. The study finds that the domain of E-Administration involves the initiatives that deal with improving internal working in the public sector. Further, it finds several differences and similarities between Jordan's E-government model and that adopted from the US. It finds that America has a longer history of using digital systems in public service provision. Also, United States is already moving from e-government to Smart Government System. Jordan's new system is still an e-government establishment rather than a Smart Government system, despite the fact that both systems have related objectives.
\end{abstract}

Keywords: e-government, e-administration, smart government, smart technologies, internet technology, e-government domains.

\section{Introduction}

The internet technology continues to gain importance in almost every institution, sector and society. Consequently, every organization needs to adopt the technology in accomplishing at least some of their processes, especially in communication. Therefore, it has become evident that management is becoming more effective with communication technology. Evidently, modern organizational and corporate management is increasing becoming difficult to manage without technology in a society where people are increasingly relying on technology for communication. It means, therefore, that the management must meet the expectations of the clients by adopting technology in some or most of their business processes [1].

The concept of e-government is relatively new in the modern world [2]. Nevertheless, it has, in the last few decades, enabled governments to serve citizens using the internet technology. In addition, technology has allowed governments to obtain, process, manipulate, store, retrieve and report data on an efficient and reliable manner [2].

In this concept, governments, similar to organizations, have achieved efficiency in decision making through the use of information and communication technology. Over the last few decades, two major concepts have been associated with the government use of the internet and communication technology-e-government and smart government. E-government has allowed governments to serve the citizens using the internet technology [3]. In addition, it has allowed governments to 
capture, obtain, process, store and report data efficiently as well as improve decision making processes [3]. Nevertheless, there have been major advances in smart technologies. Also, they have produced a better informed and connected public and globally connected economies. Combined, these factors created more opportunities for development, which has forced many governments to retying their position and roles in the modern society and development [2].

Currently, many governments around the world are beginning to consider the concept of e-government in providing public services effectively. In particular, they are realizing that data is potential for improving service delivery and citizen involvement as well as achieving integrated and seamless service delivery and developing policies and solutions for the economic and social problems facing them. Consequently, they are realizing the need for converting themselves to "smart governments" because the emergence of such technologies as social media, "mashup", mobile applications and big data analytics that are all allowing citizens to connect with their governments [4].

The research question is, "what are the differences between e-government and smart government and how will smart governments benefit modern public administrations and service delivery?' To answer this question, this paper seeks to compare and contrast between smart government and e-government. In addition, it compares the application of smart government and e-government in the United States and Jordan.

\section{Literature review}

In the last two decades, the use of the Internet technology has brought about interest in research on various fields ranging from its development and application to its impact on business, human behavior and the future. Various researchers have developed interest in its application, especially in government and administration. It has been noted that every organization needs to adopt the technology in accomplishing at least some of their processes, especially in communication. According to the work [5] management is becoming more effective with communication technology. Assets [6] organizational and corporate management is increasing becoming difficult to manage without technology in a society where people are increasingly relying on technology for communication. According to [7] management must meet the expectations of the clients by adopting technology in some or most of their business processes.

In an empirical study [8], found that e-government is effective in administration as it has enabled governments to serve citizens using the internet technology. In addition, technology has allowed governments to obtain, process, manipulate, store, retrieve and report data on an efficient and reliable manner.

According to [9], government is similar to organizations in various ways, especially in terms of administration. For instance, the author states that similar to organizations, have achieved efficiency in decision making through the use of information and communication technology. Over the last few decades, two major concepts have been associated with the government use of the internet and communication technology-e-government and smart government. According to [10] E-government has allowed governments to serve the citizens using the internet technology [2]. In addition, it has allowed governments to capture, obtain, process, store and report data efficiently as well as improve decision making processes. Nevertheless, there have been major advances in smart technologies. Also, they have produced a better informed and connected public and globally connected economies. Combined, these factors created more opportunities for development, which has forced many governments to retying their position and roles in the modern society and development [3].

According to [8], many governments around the world are beginning to consider the concept of e-government in providing public services effectively. In particular, they are realizing that data is potential for improving service delivery and citizen involvement as well as achieving integrated and seamless service delivery and developing policies and solutions for the economic and social problems facing them. Consequently, they are realizing the need for converting themselves to "smart governments" because the emergence of such technologies as social media, "mashup", mobile applications and big data analytics that are all allowing citizens to connect with their governments [4]. 
The research question is, "what are the differences between e-government and smart government and how will smart governments benefit modern public administrations and service delivery?' To answer this question, this paper seeks to compare and contrast between smart government and e-government. In addition, it compares the application of smart government and e-government in the United States and Jordan.

\section{Aim and tasks of the research}

The aim of the research is to determine the differences between e-government and smart government and how will smart governments benefit modern public administrations and service delivery.

To achieve this goal, the following tasks were set:

1. Examine the e-government system architecture in Jordan.

2. Examine the e-government use, applications and expected outcomes.

3. Compare the Jordan e-government system architecture and that of the US in terms of structure, benefits and shortcomings.

4. The definition of the terms 'e-government' and 'smart government' and their differences and similarities

Also known as e-Government, the term 'e-government' refers to the development, adoption and use of information and communication technologies (ICTs) to improve the service delivery and activities of the public sector. Although there are many definitions of the term, it is generally agreed that the use of internet-enabled application to allow interactions between the government and outside groups are the key aspects of e-Government [11]. The e-government must have three domains- Administration (improving government processes), eCitizens and eServices (connecting citizens) and eSociety (building external interactions). The purpose of the three domains is to address the problems associated with costly government process, inefficiency and ineffectiveness of administration and inconveniency respectively. To elaborate this concept further, the e-government focal domains based on the following conceptual framework (Fig. 1).

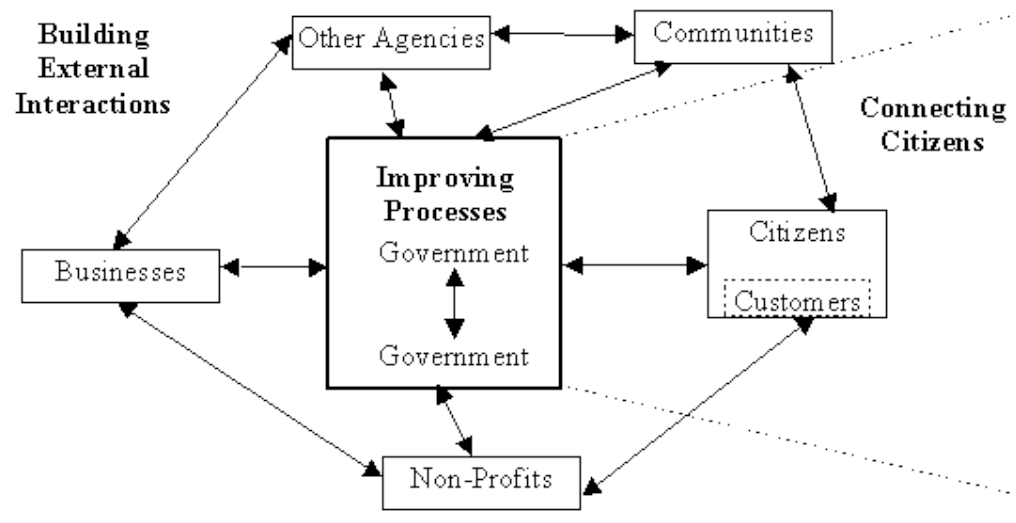

Fig. 1. The focal domains for eGovernment [4]

In-depth research into the e-Government concept reveals that the domain of e-Administration involves the initiatives that deal with improving internal working in the public sector [4]. Also, it is designed to improve government processes.

These initiatives include cutting the cost of processes by improving the ratio of input to output and cutting financial and time costs [4]. In addition, it involves managing the performance processes through planning, monitoring and controlling the processes of resources performance [4]. Further, it involves establishing strategic connections in the government by making connections between the different arms of the government, agencies, and levels as well as data stores. The idea is to ensure that the capacity to investigate, develop and implement policies and strategies that guide government processes is enhanced and strengthened. In addition, e-Administration involves 
creation of empowerment, wherein resources, authority and power for processes are transferred from their traditional locus to new locations [11].

The domain of eCitizens and eServices seeks to connect citizens. In particular, it involves the initiatives that deal with the relationships between the citizens and their government. Citizens are stakeholders and voters in their country and from them; the public sector derives its legitimacy. In addition, citizens are the customers who purchase and consume public services from their government. In a broader view, the domain of eCitizen and eServices involve talking to the citizens, wherein the government uses technology to provide the citizens with details of the public activities [11]. In this way, accountability and transparency, with public servants being required to be more accountable for the decisions and actions they make at the workplace. In addition, the domain involves listening to the citizens' needs. The government's aim is to increase the level of citizen involvement or their input into the decision making in the public sector [11].

In this way, citizen participation is encouraged and enhanced while democratization is promoted. Further, the domain involves improving the public services that are delivered to the citizens by reducing cost and enhancing quality and convenience [2].

The third and final domain, eSociety, seeks to build external relations. In this case, the initiatives involved are aimed at dealing with the relationships between the public agencies and all other parties such as government agents, community organizations, public sectors, private sector and even non-profit organizations.

The initiatives include developing communities, which is achieved through improvement of the interactions between business and the government. To achieve this, the government must seek to digitalize its works such as procurement, quality improvement and cost cutting methods [2]. Also, the domain involves development and sustenance of communities by building social and economic capacities as well as local communities [12]. In addition, the domain involves the establishment of partnerships by creating organizational groups with the potential to achieve both social and economic objectives. In this case, the public sector must be a crucial partner or a facilitator in partnership building [2].

In other words, eGovernment refers to the process of reform in the government's way of doing things such as work, information sharing and delivery of services to both external and internal clients for the benefit of the government, businesses and the citizens in general. To achieve eGovernment, the government must harness and use information technologies such as the World Wide Web (www), Wide Area Networks (WAN), the internet and mobile computing, which every government agency should apply to reach out to businesses, government arms and agencies and the citizens [2]. From the research above, it is clear that the aim of an eGovernment system is to improve the service delivery to citizens, empower the citizens through access and acquisition of information and knowledge, improve interface with citizens, business and industry and improve the effectiveness and efficiency of government workings. The idea is to achieve transparency, convenience, growth of revenue and cost reduction [13].

On the contrary, the term 'smart government' refers to the implementation of a set of working or business processes as well as the supportive information technologies that allow information and knowledge to flow seamlessly across various arms of the government as well as allow intuitive programs that lead to the provision of quality citizen services [12].

To establish Smart Government, it is necessary that government organizations seek to know the communication preferences for the citizens in order to achieve effective connections [12]. In addition, IDC finds that the government must seek to know the service and information needs of their citizens, citizen satisfaction with the government as well as citizen channel preferences [13]. There is a need for better connection between the government and the citizens for any government to provide effective and seamless information to the citizens [13]. Further, ICD states that citizens prefer to connect and interact with their governments through PCs and that many channels are preferred. In addition, the institution states that rapid smart mobile devices have significant impacts on the citizen preferences [11]. 
Unlike the eGovernment model above, the Smart Government has a "maturity model" that focuses on three domains- citizen participation, collaboration and information transparency. The citizen participation domain in government business seeks to ensure that agencies engage the public to enhance decision making and the quality of decisions they make. They are required to disperse knowledge and ensure that the public closely participates in government decisions. The second domain, information transparency in government, seeks to ensure that agencies utilize technologies to provide access of information about their decisions and operations [11].

Finally, the collaboration domain seeks to ensure that agencies use innovative and effective tools, methods as well as systems to cooperate with and engage the government at all the government levels [4].

Consequently, it is evident that the Smart Government Maturity Model seeks to create a government that is citizen directed, provides personalized information and provides $360^{\circ}$ citizen services [11]. To achieve a citizen directed government, it is important for the governments to use dispersed technology solutions in data sharing, generation of ideas, use internet-based applications to provide feedback, involve in public hearings and foster collaboration. In this model, the public is allowed to participate in moderated chat sessions, where the government initiates the subject matter. A Smart Government moves from broadcasting to its citizens without discrimination, where it provides information based on the citizen needs [2]. A government that provides $360^{\circ}$ citizen services ensures that it achieves pervasive deployment of business intelligence throughout the enterprise [2]. In addition, it seeks to ensure that business analytics are involved in the process to achieve fact-based decision-making. It also strives to extend accountability through provision of all decision makers with the right information and at the right manner and time.

Further, a Smart Government seeks to adopt customer service best practices [4]. It strives to improve the customer experience through adoption of customer service best practices as well as coordinating such service channels as on-line, in person and mails that closely involves the public [4]. To achieve this, the Smart Government must employ contact analytics and secret shoppers. In addition, it must employ focus groups as well as user groups with the aim of testing new tools, designs and website applications [2]. In addition, the focus groups and user groups help to determine the effectiveness of the changes and evaluate whether they are easy to understand and meet the demands of the audience.

Based on the above analysis, it is evident that eGovernment and Smart Government are closely related but relatively different concepts of government [2]. On its part, the concept of Smart Government implies to the use of innovative technologies, policies and business models to address environmental, social, service, and financial challenges facing the public sector. In addition, it relies on information technology systems as well as communication networks. On its part, eGovernment concept implies the use of digital tools and systems to provide effective, helpful and better public services to the people as well as businesses [2]. It is clear that the concept of e-government is different from Smart Government because it involves provision of services to and engages with citizens by leveraging internet based technologies while Smart Government involves leveraging data in decision making processes.

\section{Application of eGovernment and Smart Government in the United States versus Applica- tion of the same in Jordan}

\section{1. E-Government and Smart Government in the United States}

In the recent few years, governments across the world have increasingly shown interest and efforts to run their service delivery operations based on technologies to reduce costs, improve transparency and save time [14]. Nevertheless, not all regimes like the idea or have the capacity and willingness to employ smart and digital approach to public service delivery. While some nations have the capacity and willingness to employ the approach, others are hindered by limited funding and resources while still others are run by people who do not like the idea for various reasons [14]. Consequently, it is evident that the trends and patterns of adopting these approaches are different across 
different nations and regions in the modern world. The United Nations Public Administration Network, an agency of the United Nations, has been conducting bi-annual surveys on the application of digital technologies in the government sector [14]. Twice a year, the agency publishes the results and compares and ranks countries of the world based on their e-Government Readiness based on two indicators- state of government readiness and the extent of public or e-participation [14].

The United States is considered as the largest consumer of information and communication technology in the modern world [14]. Nevertheless, it is important to note that it does not necessarily rank the first under the e-government Readiness published by the United Nations Public Administration Network. Instead, the process of turning to e-government in the United States started in 2002, especially when the E-Government Act (2002) was signed [15]. To comply with this statute, several US departments have been making efforts to ensure that e-government approach is adopted and applied [14]. In particular, the government has been enhancing a number of websites and website features for its different departments and agencies to improve customer service and enable citizen participation. In 2009, seven years after the E-Government Act 2002 was passed, the US presidency signed the Heads of Executive Departments and Agencies on Transparency and Open Government, a memorandum that sought to improve the level of openness in the government departments and agencies [14]. It called agencies and departments to improve public trust while also improving transparency, collaboration as well as citizen participation. The idea was to enable public websites to provide and distribute information regarding the government activities and programs in various departments and agencies [12]. For instance, recovery.gov and data.gov were developed to provide the citizens with more information and ensure that they participate in public decision making. In particular, Data.gov, which was launched in 2009 after the memorandum was signed, seeks to make government information available to the citizens. For instance, it allows people to build websites, applications and mashups using the data therein [16].

The US Department of State provides a good example of the state departments and arms that have been employing information technologies and applications to move towards e-government and Smart Government models.

For instance, the department has a website that allows public participation and information access. Recently, the department has embarked on strengthening the website by making the web content mobile friendly. In this case, the department has implemented a mobile solution to connect the websites for the more than 450 embassies and consulates across the globe under the name http:// www.usembassy.gov. Any person wishing to visit the website can do it through various mobile technologies such as smart phones, feature phones and tablets. It also continues to allow PC users to access the information therein, which means that both mobile and PC users can easily access the information, regardless of their locations. Further, the department has deployed the Digitalgov Search, a search system that allows users to find content on the various websites run by the department. GSA has been involved in developing the search and federal agencies have free access to such information, which allows agencies to work closely with each other. Moreover, the department operates "My State Department", which gives citizens the opportunity to tailor content to the categories of information of their interest.

Apart from the State Department, only used here as an example, all other federal departments and agencies have taken similar or related steps to migrate to the e-government and smart government models. In particular, it should be noted that the United States, besides the UK, Singapore, Australia and Canada, has adopted and integrated digital technologies in all their departments.

For instance, among the nations using the "E-Gov $2 \mathrm{G}=$ eTransformation second-generation model of ICT-enabled govt transformation into citizen-centric and integrated government", the US is among the leading in the world [14]. Here, it is noted that the nation has moved whole-of-government perspective to digitalized system, where only three other nations, Singapore, UK, Australia and Canada have achieved the same [14].

Overall, in the White House's Office of Management and Budget, a new office called 'Office of E-Government \& Information Technology' has been created and assigned the important roles 
of transforming the federal government departments to the digital system. The office is headed by the Federal Government Chief Information Officer (CIO). It seeks to develop and provide directions in adopting, installing and using internet-based technologies. The aim is to make it easy for the businesses and people to interact with the government, enhance public participation and save taxpayer money [14].

\section{2. E-Government and Smart Government in Jordan}

Jordan, a developing nation in the Middle East region, was one of the first in the region to adopt the digital technology for public service. The nation established an e-government program in 2002 and has so far been providing public services to the citizens through internet-based applications. Although Jordan is a developing nation with limited resources compared to the United States, it has embarked on ensuring that citizens access government information online. In particular, it is important to note that the country is employing smart government and e-government models in its hope of achieving an all-government approach to digital migration. The government's Vision, as outlined by His Majesty the King of Jordan, is to ensure that the country becomes a major distributor of the economic and social development through provision of easy access to government services and information, regardless of a citizens location, ICT ability, economic and education background.

Noteworthy, the e-Government model in Jordan is based on multiple systems to ensure that every citizen, regardless of his or her education, economic ground or ICT ability, is in a position to access and understand government information. To achieve this, the government has embarked on implementing computer ad web-based e-services, G2G, G2B, G2C, cloud computing and payment gateway [14].

In 2015, the ministry of information and communication embarked on a mission to obtain proposals from qualified local partners. It sought to achieve an edge Enterprise Service Bus solution for government services [17]. This marked a major stride for the government towards implementation of e-government services to its citizens. The government, through the ministry, announced that it was embarking on a national e-government system that would provide citizens with e-services. These services are based on four categories:

1. Vertical services (services provided through a single government entity).

2. Cross-government service (services with more than one government entity and that allows recipients to submit the service at one entity and coordination is based on other entities).

3. Shared services (services developed centrally at a time to serve all other services.

4. Composite service (systems and applications as well as joint mechanism between the various sectors of the economy and the government).

The government of Jordan has set specific aims and objectives it seeks to achieve by implementing e-government-based service provision to the citizens. First, it seeks to increase the effectiveness as well as efficiency of the e-government program in achieving delivery of interconnected government services [16]. Second, it seeks to govern the reusability of web-services and policies. Third, the government is ambitious to achieve one out-of-the-box solution from a single ICT service provider and cover the main functionalities. Further, the government seeks to achieve simplified configuration and maintenance of operational procedures to save on costs and efforts. Finally, the Jordan government aims at migrating the existing we services configurations from ESB to EDGE ESB for better citizen service provision [16].

The government finally embarked on achieving these objectives in 2015 when the Ministry of Information and Communications Technology signed a Memorandum of Understanding with Zain, an international communications corporation, to achieve e-transformations of government transactions [18]. The idea is to improve interaction with the people, achieve transparency and improve the speed and process of doing government transactions. The system was implemented in the same years and since then, it has been allowing Jordanian citizens to access government data [17]. In addition, it is developed in such a manner that citizens are able to use simply the complex mobile phone devices, computers and tablets to relate with the government [18]. With the new system, the 
government of Jordan seeks to transform all its services from the previous system to a new one that will allow citizens to get services online and through any device that connects to the internet, regardless of their economic and education backgrounds and locality [19].

\section{Discussion of the research results}

The results indicate that both the U.S and Jordan are consumers of e-government system, but the former has a larger and more advanced e-government system. Because the US has been using the system for almost 2 decades now and is developed locally, it has a better and more effective system. On the contrary, Jordan's system is relatively new and is still being developed to incorporate all government work and processes. Moreover, Jordan's system is developed with the aid from IBM and other organizations, which means that the government has to outsource technical knowhow and other resources.

\section{Conclusion}

From the above research on the e-Government and Smart Government systems in the United States and Jordan, several differences can be derived. First, it is clear that America, unlike Jordan, has a longer history of using digital systems in public service provision because the systems have been in use since 2002 and were enhanced again in 2009. Jordan, on the contrary, started migrating the government services from the previous systems to an e-government platform in 2015, years after the US did to. Second, it is clear that the United States is already moving from e-government to Smart Government System. In the new model, every federal agency and department will be connected to a "whole-government and collaborative governance" specifically supported by sophisticated digital systems.

On the other hand, Jordan's new system is still an e-government establishment rather than a Smart Government system, despite the fact that both systems have related objectives. Further, it should be noted that the US's Smart Government system allows integrative and complete interaction between the government and the citizens. In particular, it also incorporates the use of the social media and applications. It allows citizens to discuss government information, actions and activities. On the contrary, Jordan's system limits the use of social media as a method of relationship building between the government and the citizens.

\section{References}

[1] Alenezi, H., Tarhini, A., Sharma, S. K. (2015). Development of quantitative model to investigate the strategic relationship between information quality and e-government benefits. Transforming Government: People, Process and Policy, 9 (3), 324-351. doi: 10.1108/tg-01-2015-0004

[2] The open data economy: unlocking economic value by opening government and public data (2013). Capgemini Worldwide, 17. Available at: https://www.capgemini-consulting.com/resource-file-access/ resource/pdf/opendata_pov_6feb.pdf

[3] Federal budget provides funding to create open data institute (2014). Digitaljournal.com. Available at: http://www.digitaljournal.com/pr/1732697

[4] Gurstein's Community Informatics. Open data: empowering the empowered or effective data use for everyone? (2010). Available at: http:/gurstein.wordpress.com/2010/09/02/open-data-empowering-the-empowered-or-effective-data-use-for-everyone/

[5] Welch, E. W., Hinnant, C. C., Moon, M. J. (2004). Linking Citizen Satisfaction with E-Government and Trust in Government. Journal of Public Administration Research and Theory, 15 (3), 371-391. doi: 10.1093/jopart/mui021

[6] West, D. M. (2004). E-Government and the Transformation of Service Delivery and Citizen Attitudes. Public Administration Review, 64 (1), 15-27. doi: 10.1111/j.1540-6210.2004.00343.x

[7] Layne, K., Lee, J. (2001). Developing fully functional E-government: A four stage model. Government Information Quarterly, 18 (2), 122-136. doi: 10.1016/s0740-624x(01)00066-1 
[8] Bonson, E., Torres, L., Royo, S., Flores, F. (2012). Local e-government 2.0: Social media and corporate transparency in municipalities. Government Information Quarterly, 29 (2), 123-132. doi: 10.1016/ j.giq.2011.10.001

[9] Fang, Z. (2002). E-government in digital era: concept, practice, and development. International journal of the Computer, the Internet and management, 10 (2), 1-22.

[10] Tolbert, C. J., Mossberger, K. (2006). The Effects of E-Government on Trust and Confidence in Government. Public Administration Review, 66 (3), 354-369. doi: 10.1111/j.1540-6210.2006.00594.x

[11] Hai, J. C. (2007). Fundamental of Development Administration. Selangor: Scholar Press.

[12] Harper, L. (2013). Gov 2.0 Rises to the Next Level: Open Data in Action. Open Source.

[13] Kaylor, C., Deshazo, R., Van Eck, D. (2001). Gauging e-government: A report on implementing services among American cities. Government Information Quarterly, 18 (4), 293-307. doi: 10.1016/s0740$624 \mathrm{x}(01) 00089-2$

[14] Ntiro, S. (2000). eGovernment in Eastern Africa. Nairobi: KPMG.

[15] Rubel, T. (2014). Smart government: creating more effective information and services. New York: Cengage.

[16] Do it online (2016). The Hashemite Kingdom of Jordan. Available at: http://www.jordan. gov.jo/wps/portal/!ut/p/b1/04_SjzS0MDE0MzU1MjbXj9CPykssy0xPLMnMz0vMAfGjzOLDLL0twrzdDQ0sPNwtDDy9DIzMfM2djA38jfWDU_P0c6McFQHxBFce/

[17] United Nations Department of Economic and Social Affairs. (2015). United Nations E-Government Survey 2015. New York: UN.

[18] United Nations E-Government Survey 2014 (2014). New York: UN Economic and Social Affairs, 284. Available at: https://publicadministration.un.org/egovkb/portals/egovkb/documents/un/2014-survey/ e-gov_complete_survey-2014.pdf

[19] Zain Jordan and Ministry of Information and Communications Technology and Palma sign MoU to achieve e-transformation of Governmental Transactions (2015). Available at: http://www.jo.zain.com/ english/media/pr/Pages/MOU-between-Zain-moict-and-palma.aspx 